\section{(a) $\mathrm{F}$}

ISSN 2450-6486

www.ehs-ss.pl

DOI: 10.38014/ehs-ss.2020.3-1.06

УДК: 378.6:37

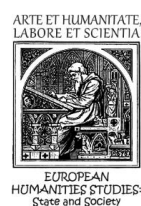

Тетяна ВЕРКIHA, Тетяна СМИРНОВА, Ірина ПОЯУБОЯРИНА, Катерина КРАСНОЩОК

\title{
Результати впровадження особистісно- орієнтованої технології у професійну освіту студентів-музикантів
}

TATYANA VERKINA, TETIANA SMYRNOVA, IRYNA POLUBOIARYNA, KATERYNA KRASNOSHCHOK. The results of the introduction of personality-oriented technology into the professional education of students-musicians. The problem of introducing personality-oriented technology into the professional education of students-musicians (the goal-motivational, emotional-volitional, semantic, operational-activity, controlling-correcting components) requires to consider the student-musician as the main value, the subject of artistic education; the need for pedagogical support for his/her personal and professional development. The technology is developed based on the analysis 
of the works of foreign and domestic scientists. In the present article, we have analyzed the features of axiological, personal, activity, phenomenological approaches as methodological guidelines, which should be implemented into the content of personality-oriented pedagogical technology. The content of the components of pedagogical technology has been determined; the progress of the experiment on the introduction of pedagogical technology has been described and we have In the present article, we have analyzed its results, which testify to the dependence of the level of the component formation on the scientific and methodological provision of the educational disciplines; the update of the content of the training courses in the educational process of the institution of higher art education.

Keywords: institutions of higher art education; personality-oriented pedagogical technology, the components of technology, student-musician, teaching methods.

Вступ. В сучасних умовах реформування професійної мистецької освіти нагальної уваги потребує вирішення проблеми підвищення якості підготовки музикантів-педагогів. Оновлення вимагають усі ианки педагогічної системи, втім ефективність освітнього процесу значною мірою залежить від вдалого використання сучасних педагогічних технологій. Технодогічність стає сьогодні домінуючою характеристикою діяльності викладача закладу вищої освіти, вона означає перехід на якісно новий щабель продуктивності і цілеспрямованої діяльності суб'єктів освітнього процесу.

Аналіз наукових джерел дозволяє з'ясувати, що процес соціалізації, особистісно-професійний розвиток студентів у системі вищої музичної освіти забезпечує впровадження особистісно-орієнтованих технологій. Утім, питання наукового обгрунтування специфіки особистісно-орієнтованої педагогічної технології в умовах професійної музичної освіти досліджено недостатньо. Актуальність обраної проблеми посилюється наявністю суперечності між вимогами суспідьства щодо впровадження у практику закладів вищої мистецької освіти особистісно-орієнтованої парадигми і недостатньо розробленою педагогічною технодогією, яка призначена забезпечити пріоритет індивідуадьності студента як носія суб'єктного досвіду.

Анадіз останніх досдіджень і публікацій. Методологічну та теоретичну основу педагогічних технологій як продукту світоглядного плюралізму розроблено у працях вітчизняних учених В. Андрущенка, I. Беха, А. Вербицького, С. Гончаренка, І. Зязюна, В. Кре- 
меня, І. Прокопенка, О. Савченко, С. Сисоєвої, О. Сухомлинської, О. Тимошенко, зарубіжних авторів Г. Еллінгтона, М. Кларина, П. Мітчелл, Ф. Персиваль, С. Споулінга, Ф. Янушкевича. Поняття «педагогічна технологія» розглядають багатоаспектно, визнаючи їі головною рисою спрямованості на підвищення ефективності освітнього процесу. Провідними ознаками сучасних педагогічних технологій визнають їхню наукомісткість, інтеграцію досягнень гуманітарних, технічних, економічних наук, взаємоузгодження процесів індивідуалізації та універсалізації освіти, гуманістичні і демократичні пріоритети, творчу спрямованість, варіативність, гнучкість (Мазайкіна, 2018, c. 11).

Сутність і зміст особистісно-орієнтованих технологій освіти грунтовно розроблена у працях вітчизняних психологів (Г. Балл, I. Бех, В. Рибалка, В. Семиченко) і педагогів (О. Пехота, А. Романишина, О. Савченко, С. Сисоєва). Питання фахової підготовки студентів музичних факультетів розглянуто у дослідженнях Н. Гуральник, А. Козир, О. Матвеєвої, Н. Мозгальової, О. Олексюк, В. Орлова, Г. Падалки, І. Полубояриної, А. Растригіної, О. Рудницької, Т. Смирнової, В. Черкасова, О. Щолокової. Вивчення наукових праць свідчить про те, що вчені поки що недостатню увагу приділяють дослідженню особистісно-орієнтованих педагогічних технологій, зокрема у закладах вищої мистецької освіти.

Мета дослідження: визначити специфіку впровадження особистісно-орієнтованих технологій в практику підготовки студентів-музикантів у закладах вищої мистецької освіти.

Виклад основного матеріалу дослідження. Передусім, слід відзначити, що стрижнем особистісно-орієнтованих педагогічних технологій має стати філософський плюрадізм, що синтезує основні положення кількох методологічних підходів на основі гуманізації та антропологізації знання. Слушними мають бути провідні положення аксіологічного підходу стосовно студента як головної цінності музичної освіти, який потребує плекання та підтримки власного особистісного становлення. Йдеться про створення у закладі (на факультеті) вищої освіти демократичного освітньо-розвивального середовища, необхідного д,я усвідомлення студентом нових особистісних і професійних смислів, змістів музично-педагогічної діяльності, виховання в особистості студента системи духовних, професійних і особистісних цінностей та якостей (Растригіна, 2002, с. 23). Зокрема, йдеться про цінності-смисли «творення», «переживання» та «став- 
лення» (Смирнова, 2008, с. 134). Цінності творення забезпечують динамізм самотворчості студента-музиканта на шляху від складної дійсності до високих духовних і професійних ідеалів, продуктивної творчої діяльності, народження новаторських, оригінальних музично-педагогічних способів дій, мистецьких інтерпретацій.

Цінності переживання виховуються в умовах естетизації освітнього процесу, розвитку здатності студентів до емпатійного переживання морадьно-естетичної цінності мистецьких творів, індивідуальної та соціальної значущості майбутньої музично-педагогічної діяльності. Слід визнати слушність виховання в процесі мистецької освіти, передусім позитивних емоцій, відгуків, емпатичних реакцій і почуттів студентів до себе, інших людей, вихованців, колег, які стають запорукою успішної освіти музикантів-педагогів, їх подальшої професійної діяльності.

Цінності ставлення (В. Мясищев, О. Лазурський, В. Франкл) мають формуватися завдяки розумінню й позитивному емоційному відношенню студента до світу музики, викладачів, представників національної та зарубіжної культури. Позитивні емоційні ставлення студента (дюбов, симпатії, антипатіі) визначають його майбутній життєвий і професійний шлях, свідоме, відповідадьне відношення до власної долі Музиканта, Просвітника, Педагога. Виховання особистості студента на основі засвоєння групи цінностей потребує формування таких професійно важливих якостей музиканта-педагога, як доброзичливість, довіра, співпереживання, доброта, доброчесність, безкорисливість.

Метододогічні подоження особистісно орієнтованого та суб'єктного підходів, що протистоять технократичній педагогіці, є підгрунтям для становлення студента як суб'єкта власної музично-виконавської та музично-педагогічної діяльності (Тимошенко, 2013, с. 12). 3 огляду на це, вкрай важливою слід уважати орієнтацію викладачів на внутрішній світ мистецької особистості студента, що передбачає корекцію не тільки змісту та досвіду зовнішньої музичної діяльності, а передусім його внутрішнього буття (мотивів, спрямованості, волі, особистісних властивостей, мистецько-творчих здібностей).

Актуальною в процесі реалізації педагогічної технології стає підготовка студента до професійної рефлексії, свідомого аналізу та корекції власного професійного становлення. Рефлексивне осмисдення змісту мистецької освіти є передумовою самоорганізації та самореалізації особистості студента, який має фокусувати увагу не 
на сталості, а нестабільності як природного стану сучасного мистецько-освітнього процесу.

Важливим має бути створення такого виховного середовища, яке забезпечуватиме діагностування, становлення і розвиток "особистісно-професійної Я-концепції, смисл та зміст особистісного зростання майбутнього музиканта-педагога.

Діяльнісний niдхід, синтезуючи різні види і форми активності студента, передбачає виховання у музикантів-педагогів уявлень про специфіку мистецької діяльності, шляхи розвитку особистості в музиці, особистісно-професійного самовираження, самовиховання, самоактуадізації музиканта-педагога. Провідні положення діяльнісного підходу реадізуються завдяки ефективному стимулюванню творчої активності майбутнього фахівця, діагностуванню та регулюванню широкого спектру мотивів, використанню продуктивних способів освіти для виховання та розвитку музикадьності як провідної професійної здібності, стимулювання студента до успішної музичної діяльності (Полубоярина, 2014, с.157).

Відтак, головним напрямом на шляху реалізації особистісно орієнтованої технології у сфері вищої музичної освіти має бути здійснення допомоги студенту в усвідомленні себе особистістю, становленні його самосвідомості, яка забезпечуватиме йому успішну музично-виконавську, просвітницьку та педагогічну діяльність. Варто сприяти засвоєнню особистісно значущих і суспільно схвалюваних смислів, цінностей, якостей, стимулювати самовираження, самоствердження і самореадізацію майбутнього митця.

Розуміння методологічної основи особистісно-орієнтованої технології професійної освіти студентів у сфері мистецької освіти дозволяе розглянути їі основні структурні компоненти та зміст. Зокрема, йдеться про ц̧ільовий, мотивацุійний, емоційно-вольовий, змістовий, операціийно-корекційний компоненти. Метою особистісно орієнтованої педагогічної технології є процес психолого-педагогічної допомоги, гнучкої корекції музиканта-педагога в процесі його суб'єктного становлення, розвитку, культурної ідентифікації, соціадізації, життевого самовизначення.

Цільовий $і$ мотиваційний компоненти мають допомагати плануванню цілей і завдань стимулювання активності особистості, іiі права на індивідуальний вибір напряму мистецької діяльності, внутрішньої потреби реалізовувати себе у музичному виконавстві або у музично-педагогічній діяльності. Стратегічною метою особистісно 
орієнтованої технології є виховання творчої особистості музиканта-педагога, здатної до успішної самореадізації у музично-педагогічній діяльності. Реалізація тактичної мети вимагає попереднього діагностування, за результатами яких викладач, разом зі студентом, визначають напрями особистісного розвитку студента. Потребують розвитку, корекції окремі сторони музикальності (музичний слух, музична пам'ять, музичне мислення, музична уява), або певні професійно важливі та особистісні якості, Я-концепція. Оперативні цілі зумовдюе успішність студента відповідно кожної музичної дисципліни, яка потребує виховання і розвитку фахових понять, способів дій, умінь, здібностей, компетентностей. У ході реалізації цільового компоненту технології слід звернутися до методів пояснення, обговорення, взаємозбагачувадьного діалогу, позитивного прикладу, ціннісно-смислових настанов (А. Бойко, С. Горбенко, Г. Падалка). Ці методи спрямовують мистецьку особистість до набуття досвіду самостворення як неповторної особистості в музичній або музично-педагогічній діяльності, закріпдюють позитивний досвід, виховують ціннісні орієнтації. Стимулювання мотивації до мистецької освіти і діяльності (їх пріоритету, значущості, новизни смислу і змісту, досягнення успіху) здійснюють методи заохочення, виховної вимоги, підтримки, орієнтації на перспективу, самооцінки та самоконтролю, змагання, дискусії, жвавого обміну думками. Доцільним є залучення як індивідуальних, так і колективних форм організації мистецької освіти.

Основою емоцийно-вольового компоненту виступає механізм впливу на емоційну та екзистанційну сферу студентів: емоційну пам'ять, уміння володіти емоційними та естетичними почуттями, настроями, здатність емоційно привласнювати образний світ у процесі розгортання музичної драматургї, розвивати емоційний інтелект (Д. Виготський). Важдивим є виховання емоційної чутливості як здатності до емоційно-естетичного переживання змісту музичних творів. Реалізацію цього компоненту забезпечують методи емоційної зацікавленості, естетизації виховного процесу, створення стану радості, захоплення людиною, емоційної драматургії, релаксації, художнього ілюстрування (Г. Падалка). В цьому аспекті варто враховувати індивідуально-психологічні та музичні здібності студентів, що означає відмову від орієнтації на середнього студента, пошук найкращих особистісних якостей, використання діагностики музикальності, волі, здатності до саморегуляції (Бех, 2015, с. 33). 
Змістовий компонент передбачає усвідомлення, запам'ятовування, переживання змісту музично-педагогічної діяльності студентами-музикантами, іiї пізнавального, естетичного, морального смислу, виявлення виховного потенціалу. Музично-педагогічний або музичний матеріал має забезпечувати актуалізацію змісту суб'єктного досвіду студента, зокрема його попереднього навчання (бесіди про досвід музичної діяльності, демонстрація вже вивчених творів, розвиток музичного слуху, уяви, уваги, музичного мислення). Виклад знань на лекціях, у підручнику має спрямовуватися як на розширення обсягу, інтегрування, узагадьнення основних, додаткових і допоміжних понять, так і на постійне перетворення набутого особистісного досвіду музичної діяльності (сприймання музики, їі розуміння, аналізу, оцінної діяльності, виконання музичних творів та імпровізацій). Доцільним є ознайомлення студентів зі змістом музично-педагогічних й музично-психологічних понять («музикальність», «музичний слух та його різновиди», «метро-ритмічна здібність», «емоційний відгук на музику», «виконавська надійність», «музична увага», «музична уява», «артистичні уміння», «музична пам'ять», «музичне мислення», «сценічне перевтілення» тощо). Варто вивчати специфіку внутрішнього і зовнішнього світу музикантів, роль активності, волі, емпатії (співпереживання, співчуття), рефлексії, самостійності для досягнення ними успішних результатів у музичній, педагогічній творчості.

Рекомендується використовувати методи і форми індивідуалізаціï mа диференціації в процесі засвоєння знань, умінь, досвіду. Зокрема, метод індивідуальних науково-дослідних завдань, який має сприяти розвитку пізнавадьної сфери, педагогічного мислення; метод самопізнання у вигляді підготовки творів, есе, малюнків. Актуальними є інтерактивні методи навчання в групі, колективі: бесіда, розповідь, пояснення, діалог як форми позитивного впливу на емоційно-почуттєву сферу учнів і студентів, методи обговорення (і корекції) 3 метою активізації самостійної думки; отримання зворотної реакції, здатності до самостійних суджень та відстоювання власної позиції. Змістовий компонент технології реалізують також такі методи організації ціннісно-смислової діяльності, як дискусії, індивідуальні або групові інтерпретації, самостійні узагальнення. Поглиблення знань, особистісно-професійних умінь музиканта-педагога відбувається завдяки методам слухової наочності, ситуації вільного вибору (змісту освіти, способів дії, репертуару, артефактів). 
Операційно-діяльніснй компонент передбачає передусім створення етико-естетичного, виховного мистецького середовища ддя забезпечення особистісного та професійного розвитку студентів. Для оволодіння способами самодіагностування, основними навчально-професійними уміннями доцільно застосовувати методи повторення, вправ, дій за зразком. Подальше формування професійного досвіду особистості студента-музиканта спонукає шукати вихід у інтенсифікацї̈ навчання, застосування елементів проблемного, контекстного і проектного навчання.

Варто рекомендувати створювати проблемні ситуації, стимулювати студентів до вирішення задач, що організуються на матеріалі виконавської та педагогічної діядьності музикантів і забезпечуються довідковою і словниковою дітературою на користь вирішення музично-професійних проблем. Важливим засобом формування особистості студента є застосування "методу прикладів" 3 метою вивчення типових випадків, проблем та ускладнень, з якими зустрічаються музиканти-педагоги у своїй професійній діяльності. Корисним засобом зростання особистості стає професійний аналіз мемуарної дітератури, відео та аудіозаписів, позааудиторні бесіди і саморефлексія навчальної професійної діяльності викладачів і студентів. Такий підхід грунтується на повазі до особистості та індивідуальності кожного студента, на відміну до орієнтації на формування абстрактного “ідеадьного” педагога-музиканта. Сучасна музична педагогіка обгрунтувала і рекомендує для виховання музиканта-педагога значну кількість методів продуктивного розвитку особистості. Це передусім методи розвивадьного навчання (задачі, завдання, прийоми розвитку пізнавальної активності, мисленнєвої діяльності учнів та студентів), також це методи діалогічного навчання, стимулювання музичної діяльності (емоційного впливу, здивування, імітаційне моделювання, родьової ідентифікації, співвідчуття, метод монтажу.

Розвиток майбутнього музиканта-педагога як яскравої особистості має також відбуватися в процесі розв'язання особистісно-орієнтованих ситуацій (Бех, 2015, с. 247), спрямованих на відтворення змісту музично-виконавської, музично-педагогічної, просвітницької діяльності, моделювання професійних і особистісних ситуацій, характерних для неї. Продуктивним способом підвищення ефективності особистісно-професійного самоствердження стає конструювання і розробка широкого спектру збірок типових задач, упорядкованих згідно основних видів діяльності музиканта, педагога. До першої 
групи мають увійти задачі для опанування вмінь учитися $i$ спілкуватися у мистецькому колективі. До другої групи доцільно підбирати особистісно орієнтовані задачі, спрямовані на розвиток музиканта-педагога як суб'єкта мистецької освіти. До третьої групи мають увійти професійно орієнтовані типові та нестандартні задачі, що відбивають різні аспекти музично-педагогічної, просвітницької та виконавської діяльності.

Контролюючо-корекційний компонент. Суттєвою ознакою особистісно орієнтованої педагогічної технології слугує апарат контродю і корекції освітньої діяльності студентів, який забезпечується системою контрольних і коригувальних блоків, що складаються з певним чином відібраних тестових завдань та коригувальних вправ (Черкасов, 2017, с. 238). Вхідне і контродьне тестування дозволяє виявдяти реальний рівень особистісного розвитку (пізнавальної, емоційної сфери, музикальності, мотивації та волі, ступінь розвитку особистісно-професійної «Я»- концепції, а також діагностувати причини їх відставань. 3 метою забезпечення поступовості навчання та індивідуалізації професійної музично-педагогічної підготовки доцільним стає застосування навчально-методичних комплектів для самостійної роботи студентів, а також розроблення робочих зошитів 3 комплексом диференційованих завдань і контрольних текстів.

Слід зазначити, що експериментадьною базою для апробації результатів впровадження особистісно-орієнтованої технології у професійну освіту студентів-музикантів стали Харківська гуманітарно-педагогічна академія (музично-педагогічний факультет) та Харківський національний університет мистецтв імені І.П. Котляревського (оркестровий та виконавсько-музикознавчий факультети). До експериментальної групи увійшли 78 студентів ХНУМ імені І.П. Котляревського, а до контрольної - 71 студент Харківської гуманітарно-педагогічної академіі.

На констатувальному етапі експерименту, враховуючи взаємозумовленість компонентів технологіі, було розроблено критерії та показники як засоби вимірювання та оцінювання рівнів сформованості (досконалий, достатній, низький) знань, умінь, навичок та особистісних якостей студента-музиканта: а) ціле-мотиваційний, спрямований на виявлення мотиваційних новоутворень студента як носія цінностей; б) емоційно-вольовий критерій слугує виявленню уміння володіти емоційними та естетичними почуттями, настроями, здатності емоційно привласнювати образний світ у процесі роз- 
гортання музичної драматургї; в) змістовий критерій відображає доцільність усвідомлення, запам'ятовування, переживання змісту усіх видів музичної діяльності студентами, їі пізнавального, естетичного, морального смислів; г) операційно-діяльнісний критерій вказує на точність, гнучність здійснення технологічного інструментарію для забезпечення особистісного та професійного розвитку студентів.

Формувальний етап експерименту був спрямований на розв'язання таких завдань, як впровадження в процесі вивчення дисциплін «Музична педагогіка», «Музична педагогіка та психологія вищої школи», «Спеціальне фортепіано», «Фортепіано», «Хорове диригування» особистісно-орієнтованої технологїі професійної освіти студентів-музикантів; перевірку ефективності науково-методичного забезпечення цієї технології; оновлення змісту вищезазначених навчальних курсів.

На контрольному етапі експерименту, враховуючи зміст, методи, форми та засоби, було здійснено педагогічний моніторинг як діагностику рівнів сформованості знань, умінь, навичок та особистісних якостей студентів-музикантів за ціле-мотиваційним, емоційно-вольовим, змістовим та операційно-діяльнісним критеріями; кількісний аналіз та порівняння результатів дослідження в екпериментальній та контрольній группах до и після експерименту із застосуванням методів математичної статистики, а саме: у визначенні середньої кількісної характеристики сформованості знань, умінь, навичок та особистісних якостей у студентів за кожним з трьох рівнів скористувадися виведенням середньої арифметичної по кожному 3 них. Узагальнені результати дослідження наведені в таблиці 1.

\section{Таблиця 1.}

Рівні сформованості знань, умінь, навичок та особистісних якостей студентів-музикантів (\%)

\begin{tabular}{|c|c|c|c|c|}
\hline \multirow{2}{*}{$\begin{array}{c}\text { Рівні } \\
\text { сформовано-сті }\end{array}$} & \multicolumn{2}{|c|}{$\begin{array}{c}\text { Експериментальна група } \\
\text { (78 студентів) }\end{array}$} & \multicolumn{2}{c|}{$\begin{array}{c}\text { Контрольна група } \\
\text { (71 студент) }\end{array}$} \\
\cline { 2 - 5 } & До експерименту & $\begin{array}{c}\text { Після } \\
\text { експерименту }\end{array}$ & До експерименту & $\begin{array}{c}\text { Після } \\
\text { експерименту }\end{array}$ \\
\hline досконалий & 5,2 & $\mathbf{2 4 , 2}$ & $\mathbf{6}$ & $\mathbf{1 0 , 4}$ \\
\hline достатній & 49,8 & 58,7 & 52,7 & 54,3 \\
\hline низький & 45 & $\mathbf{1 7 , 1}$ & 41,3 & 35,3 \\
\hline
\end{tabular}


Проведена експертиза підтвердила наявність досконалого рівня сформованості у студентів експериментальної групи знань, умінь, навичок та особистісних якостей, зокрема, їх кількість зросла з 5,2\%, що було зафіксовано до проведення експерименту, до 24,2\% і достатнього рівні 3 49,8\% до 58, 7\%; кількість студентів 3 низьким рівнем сформованості компонентів особистісно-орієнтованої технодогії зменшилась після проведення експерименту з 45\% до 17,1\%. Отже, проведений аналіз результатів експериментальної роботи свідчить про результативність запропонованої особистісно-орієнтованої технології професійної освіти студентів-музикантів, продуктивність розробленого науково-методичного забезпечення цієі технології; оновлення змісту навчальних дисциплін «Музична педагогіка», «Музична педагогіка та психологія вищої школи», «Спеціальне фортепіано», «Фортепіано», «Хорове диригування».

Висновки та перспективи подальшого дослідження. Отже, специфіка впровадження особистісно-орієнтованої технології у підготовку студентів-музикантів (ціяемотиваційний, емоційно-водьовий, змістовий, операційно-діяльнісний, контролюючо-корекційний компоненти) у закдадах вищої освіти вимагає інтеграції методологічних настанов щодо студента як головної цінності, суб'екта мистецької освіти, важдивості педагогічної підтримки його особистісно-професійного становлення. Розвитку та корекції потребують цілемотиваційна сфера, емоційна чутливість, воля, музикальність як складна фахова здібність. Варто зосередити увагу на формуванні інтегрованої системи морально-естетичних, особистісних, музично-професійних цінностей, поглиблення творчо-естетичного досвіду сприймання, розуміння, переживання, виконання та творення музики. Усі компоненти педагогічної технології мають забезпечувати саморозвиток, самоосвіту та здатність до самореалізації студента-музиканта.

\section{References:}

1. Бех І.Д., 2015. Вибрані наукові праці. Виховання особистості. Том 2. Чернівці: Букрек.

2. Мазайкіна, I.О., 2018. Формування готовності майбутніх учителів до застосування особисто орієнтованих педагогічних технологій навчання іноземних мов у професійній діяльності. (Дис...канд... пед.н.). Вінніцький національний педагогічний університет, Вінниця. 
3. Олексюк, О.М., 2009. Музично-педагогічний процес у вищій школі. К.: Знання України.

4. Полубоярина, I.I., 2014. Теоретичні і методичні засади професійної підготовки обдарованих студентів музичних спеціальностей у вищих навчальних закладах. (Дис. док. пед. наук). Харківський національний університет мистецтв ім. І.П. Котляревського, Харків.

5. Растригіна, А.М., 2002. Педагогіка свободи: метододогічні та соціальнопедагогічні основи: монографія.ТОВ «Імекс $\lambda$ ТА».

6. Смирнова, Т.А., 2008. Теорія та методика диригентсько-хорової освіти у вищих навчальних закладах; психодого-педагогічний аспект: монографія .Горлівка: ПП» ВидавництвоЯіхтар».

7. Тимошенко, О.І., 2013. Філософія педагогічних технологій в контексті сучасних освітніх тенденцій. (Дис. доктора філос. наук). Київ.

8. Черкасов, В.Ф., 2017. Основи наукових досліджень у музично-освітній галузі: [підручник].- Кіровоград: РВВ КДПУ ім. В. Вінниченка. Харків: ФОП Озеров.

\section{Transliteration of References:}

1. Bekh I.D., (2015). Vybrani naukovi pratsi. Vykhovannia osobystosti. Tom 2. Chernivtsi: Bukrek.

2. Mazaikina, I.O., (2018). Formuvannia hotovnosti maibutnikh uchyteliv do zastosuvannia osobysto oriientovanykh pedahohichnykh tekhnolohii navchannia inozemnykh mov u profesiinii diialnosti. (Dys...kand... ped.n.). Vinnitskyi natsionalnyi pedahohichnyi universytet, Vinnytsia.

3. Oleksiuk, O.M., (2009). Muzychno-pedahohichnyi protses u vyshchii shkoli. K.: Znannia Ukrainy.

4. Poluboiaryna, I.I., (2014). Teoretychni i metodychni zasady profesiinoi pidhotovky obdarovanykh studentiv muzychnykh spetsialnostei u vyshchykh navchalnykh zakladakh. (Dys. dok. ped. nauk). Kharkivskyi natsionalnyi universytet mystetstv im. I.P. Kotliarevskoho, Kharkiv.

5. Rastryhina, A.M., (2002). Pedahohika svobody: metodolohichni ta sotsialnopedahohichni osnovy: monohrafiia.TOV «Imeks LTD».

6. Smyrnova, T.A., (2008). Teoriia ta metodyka dyryhentsko-khorovoi osvity u vyshchykh navchalnykh zakladakh; psykholoho-pedahohichnyi aspekt: monohrafiia .Horlivka: PP» VydavnytstvoLikhtar».

7. Tymoshenko, O.I., (2013). Filosofiia pedahohichnykh tekhnolohii v konteksti suchasnykh osvitnikh tendentsii. (Dys. doktora filos. nauk). Kyiv.

8. Cherkasov, V.F., (2017). Osnovy naukovykh doslidzhen u muzychno-osvitnii haluzi: [pidruchnyk].- Kirovohrad: RVV KDPU im. V. Vinnychenka. Kharkiv: FOP Ozerov. 
Authors

Tatyana Verkina

Candidate of Arts Criticism, Professor,

People's Artist of Ukraine,

Rector of Kharkiv National I. P. Kotlyarevsky

University of Arts,

Kharkiv, Ukraine

E-mail:mariia_bondarenko@ukr.net

ORCID ID: 0000-0002-1541-1959

Tetiana Smyrnova

Doctor of Pedagogical Sciences, Professor,

Department of Theory and Methods

of Artistic Education,

Kharkiv National I. P. Kotlyarevsky University of Arts,

Kharkiv, Ukraine

E-mail: smyrnova.tetiana@gmail.com

ORCID ID: 0000-0002-2931-8288

Iryna Poluboiaryna

Doctor of Pedagogical Sciences, Assistant Professor,

Head of the Department of Theory

and Methods of Artistic Education,

Kharkiv National I. P. Kotlyarevsky University of Arts,

Kharkiv, Ukraine

E-mail:195828@ukr.net

ORCID ID: 0000-0003-1911-8183

Kateryna Krasnoshchok

Candidate of Arts Criticism,

Professor of Piano Department,

Public Institution 'Kharkiv Humanitarian

Pedagogical Academy' Kharkiv Regional,

Kharkiv, Ukraine

E-mail: katryn4444@gmail.com

ORCID ID: 0000000308046807 
ТЕТЯНА ВЕРКІНА, ТЕТЯНА СМИРНОВА, ІРИНА ПОЛУБОЯРИНА, КАТЕРИНА КРАСНОЩОК. Резудьтати впровадження особистісно-орієнтованої технології у професійну освіту студентів-музикантів. Проблема впровадження особистісно-орієнтованої технології у професійну освіту студентів-музикантів (цุілемотиваційний, емоціийно-вольовий, змістовий, операційно-діяльнісний, контролюючо-корекційний компоненти) вимагае роглядати студента-музиканта як головну цінність, суб'єкта мистеиьької освіти; необхідності педагогічної підтримки його особистісно-професійного становлення. Технологія розроблена на основі анахізу праць зарубіжних і вітчизняних учених. У статті проанахізовано особливості аксіологічного, особистісного, діяльнісного, феноменологічного підходів як методологічних настанов, щзо мають бути імплементованими у зміст особистісно-орієнтованої педагогічної технологіі. Визначено зміст компонентів педагогічної технології; описано хід експерименту щодо впровадження педагогічної технолоzіï та проаналізовано його результати, які свідчать про залежність рівня сформованості компонентів від науково-методичного забезпечення навчальних дисциипхін; оновлення змісту навчальних курсів у навчально-виховному процесі закладу вищої мистецьької освіти.

Ключові слова: заклади вищої мистецьької освіти; особистісно-орієнтована педагогічна технологія, компоненти технологї̈, студент-музикант, методи навчання.

ТАТЬЯНА ВЕРКИНА, ТАТЬЯНА СМИРНОВА, ИРИНА ПОЛУБОЯРИНА, ЕКАТЕРИНА КРАСНОЩОК. РезУльтати внедрения дичностно-ориентированной технологии в профессиональное образование студентов-музыкантов. Проблема внедрения хичностно ориентированной технологии в профессиональное образование студентов-музыкантов (целемотивационный, әмоционально-волевой, смысловой, операциионно-деятельностный, контрольно-корекциинный компоненты) требует рассмотрения студента-музыканта как главную ценнность, субъвекта художественного образования; необходимости педагогической поддержки его личностного профессионального становления. Технология разработана на основе анализа трудов зарубежных и отечественных ученых. В статье проанализированы особенности аксиологического, хичност- 
ного, деятельностного, феноменологического подходов как методологических установок, которые должны быть имплементированны в содержание личностно-ориентированной педагогической технологии. Определенно содержание компонентов педагогической технологии; описан ход эксперимента относительно внедрения педагогической технологии и проанализировань его результать, которые свидетельствуют о зависимости уровня сформированности компонентов от научно-методического обеспечения учебных дисицилин; обновления содержания учебных курсов в учебно-воспитательном процессе заведения высшего музыкального образования.

Ключевые слова: заведения высшего музыкального образования; личностно-ориентированная педагогическая технология, компоненты технологии, студент-музыкант, методы учебь.

TETIANA WIERKINA, TETIANA SMYRNOWA, IRYNA POŁUBOJARYNA, KATERYNA KRASNOSZCZOK. Rezultaty wprowadzenia technologii zorientowanej na osobowość w kształceniu zawodowym studentów muzyków. Problem wprowadzenia technologii zorientowanej na osobowość w kształceniu zawodowym studentów muzyków (element dotyczacy motywacji i celów, woli i emocji, treści, aktywności operacyjnej, kontroli i korekcji) wymaga postrzegania studenta-muzyka jako głównej wartości, przedmiotu edukacji artystycznej; potrzeba wsparcia pedagogicznego jego rozwoju osobistego i zawodowego. Technologia została opracowana na podstawie analizy prac zagranicznych $i$ krajowych naukowców. Artykut analizuje cechy podejścia aksjologicznego, osobistego, aktywnościowego i fenomenologicznego jako wytycznych metodologicznych, które należy wdrożyć w treści technologii pedagogicznej zorientowanej na osobowość. Określono treść elementów technologii pedagogicznej; opisano przebieg eksperymentu dotyczacego wprowadzenia technologii pedagogicznej i przeanalizowano jego wyniki, które wskazuja na zależność poziomu ukształtowania elementów od naukowo-metodologicznego wsparcia dyscyplin akademickich; aktualizacja treści kursów edukacyjnych w procesie edukacyjnym instytucji szkolnictwa wyższego.

Słowa kluczowe: artystyczne uczelnie wyższe; technologia pedagogiczna zorientowana na osobowość, elementy technologii, student-muzyk, metody nauczania. 